\title{
THE THREAT OF DISEASE ON FEMALE IDENTITY IN EMILE ZOLA'S NOVELS
}

Irina DAVID ${ }^{1}$

\begin{abstract}
Disease and its effect on the body and personal autonomy, as well as its influence on the social position of the diseased person, are among the key themes in the novels of the $19^{\text {th }}$ century French writer Émile Zola. When it comes to female characters, illness has a multifold impact, having both physical and psychological effects, erasing in extreme cases female identity itself. The aim of this article is to offer insights into how sickness is depicted as a menace that leaves female characters deprived of any power they might have by affecting their appearance, which is the main indicator of their social identity and the key instrument they can use to establish and maintain relationships, and by taking away their ability to control themselves and how they are seen by others.
\end{abstract}

Keywords: disease, female body, female identity, Émile Zola. DOI: $10.24818 / \mathrm{SYN} / 2021 / 17 / 2.06$

\section{Introduction}

This article is centred around the idea that in Émile Zola's literary world female body and how it is perceived by others represent metaphors illustrating how women themselves are seen in the French author's novels, as well as in $19^{\text {th }}$ century French society, which he was inspired by when creating his characters and plots. Valued mainly - if not exclusively - according to her image, one of a $19^{\text {th }}$ century woman's key roles was to fascinate by eliminating from her appearance natural imperfections and by projecting an artificial image adapted to to the viewers' expectations (Baudelaire, 1968). Her appearance had to match and indicate her male partner's social position and wealth (Aron, 1980), as well as to comply with social rules if the respective woman wanted to be accepted as a member of her community.

His contemporaries' views have obviously left their mark on Zola, whose portrayals of his female characters' bodies and artificially constructed image, far from being objective and focusing on purely anatomic features, are based on a subjective approach, according to which women are described through the lens of those who are watching them. Female anatomy is only interesting and worth analysing if it attracts a viewer's eyes and raises desire or if it has the potential to do so (Cnockaert, 2003). The female character herself has little self-agency: while she can and is expected to do everything it takes to fulfil her role of projecting the

\footnotetext{
${ }^{1}$ Irina David, Bucharest University of Economic Studies, irina.david@ rei.ase.ro
} 
image that those around her expect to see, she only becomes beautiful or desirable when the other characters - usually male - decide she is worthy of their attention (Rejchwald, 2018). From this perspective, appearance, a combination of natural traits and skilful use of makeup, clothing and hairstyling becomes the most important indicator of a woman's social identity and of her ability to build connections with others. Furthermore, it offers clues - that only a men's eyes can see - regarding the respective woman's sexual potential and her willingness to engage in a romantic relationship with the respective man (David, 2021). Any refusal to comply with the accepted rules in terms of fashion, hairstyling, makeup use and overall public image is synonym to a refusal to be part of the community and is followed by rejection and punishment. Surprisingly, in Zola's work acceptance of social norms is also often punished, since by following expectations women increase their chances of being perceived as objects of desire, thus becoming a distraction for the male characters and a threat to their ability to perform their duties.

If we accept the premise of the female body as a metaphor for female social identity, then it is easy to understand why any form of disease is perceived as the greatest danger possible for the female characters, and at the same time as a saving element for the male characters and implicitly for the social order that they are able to protect once they are freed from under women's influence. It is interesting to notice that in the mind of the one who is affected by an illness it is not the pain itself that causes fear and concern, but rather the impact that the disease has on the body, which loses its shapes and grace, making the woman unable to attract and cause feelings other than pity or the desire to be taken care of. Closely connected to sexuality and its sinful connotations, menstruation, pregnancy and the act of giving birth, inherent traits belonging exclusively to feminine biology, are also included in the range of phenomena that frighten female characters due to the way in which they deform the body.

In the $19^{\text {th }}$ century French society disease of the female body was not seen as something rare or extraordinary. On the contrary, it is one of the main characteristics of womanhood, as shown by one of the analysts of the period's beliefs, who summarized medical perceptions of this issue by using the expression "woman, so sick; and sick because a woman". (Aron, 1980: 81, translated by the author) Representing a mystery for men, women remain to a great extent unknown to doctors themselves, as they cannot always find a logical explanation for female unpredictable physical condition and reactions. The frailty of a woman's health and the fact that "female physiology is a pathology" (Aron, 1980: 86, translated by the author) cause constant fascination mixed with concern and worry. Pregnancies and monthly bleeding that lead to periodical imbalances and changes in appearance and which emphasize the image of the female body as an unstable system only increase the confusion. 


\section{Disease as a Threat to Female Existence}

Zola seems to echo his contemporaries' ideas about female pathology. In his work, this perception is accompanied by a negative view with regard to women's bodies as instruments of seduction, as well as with regard to sexuality. In many cases, disease comes as a result of sexual encounters or as penalty for actions against men, forcing female characters to bear "the stigma of their alterity and of their gender" (Bertrand-Jennings, 1977: 50, translated by the author), taking away their power by eliminating their natural beauty or their ability to construct the artificial appearance they want to project, which are the only weapons they have for attracting, seducing and influencing those around them.

The loss of female grace is associated with a loss of femininity itself. Reduced to its raw physical state, flesh is no longer the source of passion and ceases to represent an erotic threat for men. When Lazare, the male character from La joie de vivrel The Joy of Life takes Pauline to her bed after she faints in her room, he experiences no unease and the only feeling that dominates him is that of brotherly protection. The English translation of the book, where the translator only shows that "all hesitation on his part vanished, and he took her up in his arms and carried her to her bed full of fraternal anxiety" (Zola, 1915: 108) does little justice to the original version in French, in which Zola clearly mentions Pauline's nudity and Lazare's initial hesitation in touching her, which soon disappears and is replaced by indifference to her femininity and concern for her health (Zola, 1884: 230-231). It is obvious that in this specific instance nudity is deprived of its sexual connotations, given that its power to seduce has been overthrown by an extreme weakness of the entire body.

In some cases, the loss of a woman's ability to produce desire is symbolised by a deformation and reduction of female body shapes. Affected by a disease that slowly takes away all her vital energy, Geneviève Baudu, the cousin of Denise, key female character in Au Bonheur des Dames/ The Ladies' Paradise, becomes "so very thin, under the bed-clothes, that one hardly suspected the form and existence of a human body". (Zola, 1895: Chapter XIII) Her words clearly show that she is not concerned with the pain that disease causes or with its potentially fatal outcome as much as she is with the way in which her damaged appearance somehow erases her quality as a woman and makes her unworthy of the attention of the man she loves. When Denise tries to comfort her, she uses the image of her body affected by disease to illustrate why her own existence no longer has any value:

And Denise having remonstrated, assuring her that she was not so bad as all that, she cut her short again, suddenly throwing off the bed-clothes with the chaste gesture of a virgin who has nothing to conceal in death. Naked to the waist, she murmured: "Look at me! Is it possible?" 
Trembling, Denise quitted the side of the bed, as if she feared to destroy this fearful nudity with a breath. It was the last of the flesh, a bride's body used up by waiting, returned to the first infantile slimness of her young days.

Geneviève slowly covered herself up again, saying: "You see I am no longer a woman. It would be wrong to wish for him still!" (Zola, 1895: Chapter XIII)

After she is deprived of her seduction abilities, the woman experiences a symbolic return to her childhood, an age when her body was perceived as neutral, which eliminated difference and alterity, thus making the female body harmless. The same return appears in the case of Mrs. Raquin, who initially finds pleasure in the benefits brought by the impossibility to move her members, which allows her to spend time day-dreaming and not worrying about taking care of herself or complying with the household duties attached to her position as a woman:

Madame Raquin was happy, happy at the care and affection bestowed on her by her dear children. She had always dreamed of ending in this gentle way, amidst devotedness and caresses. Certainly she would have been pleased to have preserved her speech, so as to be able to thank the friends who assisted her to die in peace. But she accepted her condition without rebellion. The tranquil and retired life she had always led, the sweetness of her character, prevented her feeling too acutely the suffering of being mute and unable to make a movement. She had entered second childhood. She passed days without weariness, gazing before her, and musing on the past. She even tasted the charm of remaining very good in her armchair, like a little girl. (Zola, 1867: 154)

However, the illusion of a benevolent illness ends when she becomes aware of the fact that her son was killed by his wife Thérèse and her new husband Laurent. Incapable to express her own pain or to tell others what she had found out, she is betrayed by her own body, which becomes a prison that she cannot escape. A possessive mother, who had deprived her son of his masculinity and freedom of choice by treating him as a sickly child throughout his entire life, she is punished by an illness that starts from her legs - thus reducing her ability to move freely and then spreads throughout the entire body. The same symptoms are experienced by Mrs. Chanteau, guilty of having influenced her son Lazare and having convinced him to reject Pauline, a healthy and fertile woman, who had spent most of her life taking care of him, and choose the sickly, but richer Louise instead. In her case, disease leads to a frightening deformation of the body, which causes feelings of pity and horror in her son's heart, "his mother having shown him her knees, the sight of her poor swollen limbs, puffed out by oedema, huge and pallid, looking already like lifeless trunks" causing "panic-stricken tenderness". (Zola, 1915: 157)

Just as it happens to Mrs. Raquin, Mrs. Chanteau's disease spreads from her legs and conquers the rest of her body. By the time Lazare becomes aware of how 
seriously ill his mother is, her womb, symbol of procreation, has also been attacked by the virus.

In Le Rêve/ The Dream, Angélique is also affected by the failure of her feet, as well as by the loss of body shapes, but for her the disease does not have a punitive role, acting instead as a barrier protecting the character's chastity even in spite of her own wishes and intentions. Thus, the weakness of her legs prevents Angélique from falling into temptation and escaping with Félicien despite her adoptive parents' and his father's rejection of them as a couple. Charmed initially by the idea of eloping, she cannot do it because her body becomes so weak that she cannot leave her room. The two finally gain their parents' approval and get married, but the young bride dies as they are leaving the wedding chapel. Although pure and innocent, and although in her case physical pain is sublimated, one cannot fail to notice that she is not spared from the negative impact of the disease. Death is the only one that can help her escape from the trap of her existence and prevent her from becoming involved in a sinful sexual relationship, albeit with her own husband (Zola, 1888).

There is no sublimation and no mercy when it comes to Nana. Famous for using her seducing powers to dominate men and for being able to make them forget their duties and even step away from their religious beliefs, as Count Muffat does to be with her, she is punished by means of chickenpox, which completely cancels her beauty and brings to the surface all the decay that was hidden behind her carefully construed appearance. Shortly after her death, she is already decomposing and her demolished body is no more than:

(...) a heap of matter and blood, a shovelful of corrupted flesh thrown down on the pillow. (...) Venus was rotting. It seemed as though the poison she had assimilated in the gutters and on the carrion tolerated by the roadside, the leaven with which she had poisoned a whole people, had but now remounted to her face and turned it to corruption. (Zola, 1880: Chapter XIV)

Ironically, she gets the disease that will kill her in such a horrifying manner not from one of her lovers, but from performing an exclusively feminine activity: nursing her son. The baby eventually dies, but not before passing on the illness to his mother. There is no redemption for her, and even when she does the right thing, trying to nurse and take care of her baby, the consequences of her actions against men are there to haunt her. There seems to be little, if any blame cast on the men that decided to take advantage of her body, as if their self-agency did not exist at all and she was the only one who participated in their amorous encounters. At the end, despite the apparent control she had over the others, she remains a victim, and before death she is "stripped of the only resource patriarchal society valued - her body". (Sekanics, 2017: 6) From this perspective, death is the only logical outcome of her illness, given that she "would not have been able to survive without her body" (Sekanics, 2017: 6) in a world in which this is the only commodity of value that a woman has to offer.

SYNERGY volume 17 , no. $2 / 2021$ 
As shown by Rossi (2017) in her analysis of the novel, its end, when Nana's body is horribly maimed by the disease, matches its beginning. The same crowd that was admiring Nana at the beginning of the novel, when the courtesan was in full glory, is there after she dies and their fascination mixed with rejection remains just as strong. The disgust that the viewers are feeling, which does not prevent them from wanting to see the decomposing body that many of them had once watched admiringly despite their own will, as well as their carelessness for what the female character had gone through illustrate "contemporary fears of the female body, the ambient society's hypocrisy, misogyny and contempt for the lower classes". (Rossi, 2017: 283)

\section{The Negative Impact of Natural Biological Changes on the Female Body}

Apart from diseases that come from external sources and attack the female body, there are also internal enemies that Zola's female characters fear. One of them is the monthly period, perceived as an aggression against the body, as a constant event that makes it weak, and as a reminder that the woman has failed to procreate. Especially in the case of young women, this event causes fear and shame, mainly because many of them have no one to warn them about it before they first experience it.

In La joie de vivre/ The Joy of Life, Pauline's first menstrual cycle is preceded by the symptoms of an illness. The physician called to check on her warns her aunt that she might suffer from a severe shock when it happens. His predictions prove to be true, because the aunt later finds Pauline in her bed soaked in blood and completely terrified, thinking she is about to die. The words used to describe her state paint the image of a body that has been the subject of an aggression through which the veins are emptied of blood. After Lazare marries Louise, Pauline experiences once again a similar sensation, when she watches her own nudity thinking of how her vital energy is wasted (Zola, 1915: 249; Zola, 1884: 515). Far from bringing her joy and confirming to her that she is healthy, this time loss of blood reminds her that her own femininity is worthless as long as the man she could have created a baby with, thus fulfilling her role as a woman, had chosen someone else as the object of his desire.

Similar to an injury inflicted violently, menstruation leads to the weakness of the entire body, slowly deprived of its energy, while at the same time having a psychological impact on the woman made aware of yet another wasted opportunity to procreate. Seeing herself attacked and deprived of one of her key social roles, the female character is reminded of the sterility of her body, suggested ironically by means of the flow of blood that could have been the symbol of procreation, an exclusively feminine ability. 
Unfortunately, even when procreation is possible and the woman becomes a mother, this results in a scary deformation of the pregnant woman's body and in an often-terrifying childbirth, which bring to mind the idea of death more than that of life-giving. Far from being a source of joy, a pregnant woman's womb is watched with the same mixture of worry and rejection caused by disease, and any form of feminine grace is erased by the changes taking place after a child is conceived. When she first watches Louise pregnant, Pauline does not see in her the beautiful elegant lady that had seduced Lazare, but a clumsy woman, unable to move around easily and using clothing to hide the unwanted changes in her body. As already shown in this article, the same inability to move freely and dissolution of body shapes appear as a result of crippling and even deathly disease. When Pauline hugs Louise and feels her rounded womb touch her, she feels horror and pity (Zola, 1884: 585).

Childbirth itself is an event that inflicts unbearable pain on the future mother, while at the same time endangering her and her new-born's life without offering any guarantee that any of them will be alive at the end of the procedure.

Already deformed, the body subjected to physical suffering loses any form of beauty and feminine traits and eventually the woman herself stops being aware of her nudity exposed in front of the others. At the beginning of her birth, Louise is still concerned when she thinks that a stranger might see her while she cannot control herself and while her appearance is not the one she would like to project. Later, her shyness disappears and she stops caring about what happens around her:

Louise was fully conscious, but very low. She offered no objection to a doctor now; her sufferings were too great. When he began to speak to her she simply answered: 'Kill me; kill me at once'.

There came a cruel and affecting scene. It was one of those dread hours when life and death wrestle together, when human science and skill battle to overcome and correct the errors of Nature. More than once did the Doctor pause, fearing a fatal issue. The patient's agony was terrible, but at last science triumphed, and a child was born. It was a boy. (Zola, 1915: 288)

The description above, a translation in English of Zola's original text, is a mild and significantly censored summary of the episode as presented by the French novelist, who vividly describes Louise's psychological and physical pain, the reaction of the people that were present in the room and the efforts that the doctor had to make to help her painfully deliver her breathless son, whom Pauline manages to save after many efforts, long after the doctor and the midwife had given up on him.

In the French version, it is clearly shown how Louise, losing control due to the physical pain, stops caring about her appearance, feeling and being compared to an inanimate object. Naked in front of the doctor, the midwife, her husband Lazare and Pauline, she no longer acknowledges their presence and is not bothered by 
their touch (Zola, 1884: 630). When the woman becomes unaware of her own nudity the others begin to show the same indifference. She stops being seen as a woman and a potential source of attraction and instead she provokes pity. The mystery of her naked skin is not perceived as appealing anymore and sexual interest is replaced by feelings of horror, even disgust when the viewers are faced with the reality of a body destroyed by birth, a process compared by Zola to that of cutting trees with the use of an ax (Zola, 1884: 630-631).

Just as the menstrual cycle, the birth of the child is perceived by the mother as an injury, an aggression against her body. While struggling to give birth to her son, Louise feels repeatedly that she is the victim of a painful murder, that her body is torn apart the way butchers do to the sacrificed animals. (Zola, 1884: 636) Later, she starts fighting Pauline and the midwife that are trying to keep her still, thinking that they are torturing her and trying to kill her (Zola, 1884: 637-638). Furthermore, during the description of her labour the novelist often suggests that she seems to be dying or even to have died by referring to her lack of movement, slight breathing, face expressions and impossibility to get warm (Zola, 1884: 634, 640, 641-642).

Her pain causes pity and at the same time a certain feeling of rejection from her husband, who is so overwhelmed by the image of the painful birth that he experiences no joy at the news that his son is finally born:

Lazare, who had turned his face to the wall, was sobbing, and burst out into tears. He had been a prey to the keenest mental torture during the progress of the operations, and he thought despairingly that it would be preferable for them all to die rather than to continue living if such intense agony was to be mingled with life. (Zola, 1915: 288)

The same unease and negative emotional reactions can be seen when he is prompted to get close to his wife and touch her. Far from helping the two reconnect, this only seems to enhance the distance between them and the husband's apparent refusal or inability to comfort her becomes obvious:

(...) Pauline bent over Louise and kissed her on the forehead. 'Come and kiss her', she said to her cousin.

He came and stooped down over his wife; but he shuddered when his lips touched her brow, which was moist with icy perspiration. Louise lay there with her eyes closed, and seemed to be no longer breathing. Lazare leaned against the wall at the foot of the bed, trying to stifle his sobs. (Zola, 1915: 288)

Having the same effect on the female body as a disease, childbirth destroys female appearance and makes her unable to be perceived as a subject of desire. In this way, it punishes the woman for having tempted the male character - even if the respective character happens to be her husband - and turning him into her accomplice in sinful sexual encounters. At the same time, it leaves the affected 
woman with a choice: remain a mother and accept that she will no longer be perceived as an attractive woman or reject motherhood and regain her ability to be seen as an appealing person. Louise goes "from seductress to mutilated birth mother and then to seductress again" and, "since her desirability was marred by childbirth, she will voluntarily eliminate all motherly qualities in herself". (Hennessy, 2002: 219-220) She will go back to investing time and efforts in building a coquettish appearance for herself and she will completely ignore her son, having no interaction with him whatsoever. It is Pauline who becomes his care-taker, just as she takes care of all the members of the family, and who finds joy in spending her time with him.

\section{Conclusions}

Dedicated to an analysis of female illness caused by external and internal factors and of its impact on the body and on feminine identity itself, this article highlights the devastating consequences of disease, seen as the main threat against the very existence of Zola's female characters. Prisoners of their own body and living solely due to their appearance, deprived of any form of spirituality, they remain blocked in a vicious circle that makes them victims of their own, as well as men's sexuality. Although as women they are expected to attract others and to make them feel fascination, they are blamed for this very ability, since their influence on men is seen as a distraction that reduces their control and prevents them from exercising their authority. Any disease, including here exclusively female biological traits as monthly periods and childbirths, appears as a punishment, as it makes the body weak and destroys its appearance, thus erasing any value the respective woman might have in society and making her unable to establish relationships based on feelings that exceed those of pity and the desire to protect. By weakening the body and changing its carefully built image, illness takes away any power the woman might have and reduces her to a role that patriarchal society feels comfortable with: that of a completely harmless human being who has lost control over herself and those around her, who needs being taken care of and who is fully dependent on others.

\section{References and bibliography}

Aron, J. P. (Ed.). 1980. Misérable et glorieuse la femme du XIXe siècle, Paris: Fayard.

Baudelaire, C. 1968. Curiosités esthétiques, Paris: Hartmann.

Bertrand-Jennings, C. 1977. L'éros de la femme chez Zola. De la chute au paradis retrouvé, Paris: Klincksieck.

Cnockaert, V. 2003. "Du marbre et du chiffonné. Propos sur la beauté dans l'oeuvre d'Émile Zola", in Etudes Françaises, 39(2) : 33-45.

David, I. 2021. "Images of the Female Body in Émile Zola's Novels: Views of Womanhood in 19th Century French Society", in Ciolăneanu, R. and 
Marinescu, R.E. (eds.). Handbook of Research on Translating Myth and Reality in Women Imagery Across Disciplines, Hershey: IGI Global: 301318.

Hennessy, S. 2002. "Killing off the Mothers", in Neophilologus, 86: 215-223.

Rejchwald, J. R. 2018. "Détail, signe, tache: La représentation du corps dans le roman d'Émile Zola", in Roczniki Humanistyczne, 66(5): 75-90.

Rossi, R. 2017. "Writing Disgust, Writing Realities. The Complexity of Negative Emotions in Émile Zola's Nana", in Jandl, I., Knaller, S, Schönefellner, S. and G. Trockner (eds.). Writing Emotions: Theoretical Concepts and Selected Case Studies in Literature, Bielefeld: Transcript Verlag: 277-294.

Rosso, A. 2012. Female Sexuality in French Naturalism and Realism, and British New Woman Fiction, 1850-1900, University of Exeter, Thesis for the degree of Doctor of Philosophy in English.

Sekanics, J. 2017. "The Predetermined Deterioration of the Female Body in Zola's Nana", in TCNJ Journal of Student Scholarship, XIX: 1-8.

Zola, E. 1867. Thérèse Raquin. Transl. and ed. by Vizetelly, E.A.. Accessed on 13 February 2021 from https://www.globalgreyebooks.com/content/books/ ebooks/therese-raquin.pdf.

Zola, E. 1880. Nana. Transl. by Stirling J. Accessed on 13 February 2021 from https://onemorelibrary.com/index.php/en/?option=com_djclassifieds\&forma $\mathrm{t}=\mathrm{raw} \&$ view $=$ download\&task=download $\&$ fid $=9458$.

Zola, E. 1884. La joie de vivre, Paris: Charpentier et Cie. Accessed on 13 February 2021 from https://beq.ebooksgratuits.com/vents/zola-12.pdf.

Zola, E. 1888. Le rêve. Accessed on 30 May 2021 from https://www.gutenberg. org/files/17533/17533-8.txt.

Zola, E. 1895. The Ladies' Paradise. Transl. and ed. by Vizetelly, E.A. London: Hutchinson \& Co. Accessed on 13 February 2021 from http://www.gutenberg.org/files/54726/54726-h/54726-h.htm.

Zola, E. 1915. The Joy of Life. Transl. and ed. by Vizetelly, E.A. New York: The Marion Company.

\footnotetext{
The author

Irina David is an Associate Professor with the Department of Modern Languages and Business Communication from the Bucharest University of Economic Studies. Her areas of research include aspects related to innovative methods for teaching business communication in English, cultural issues and the development of multilingual competences, enhancing critical thinking skills, or facilitating the integration of students in a wide range of professional and cultural contexts. She is the (co-)author of textbooks on business communication in English and on cultural studies, as well as of scientific articles which focus on cultural and methodological topics. She also participated in multinational projects aimed to promote multilingualism and intercultural competences and the development of useful tools for the (self-)assessment of these skills, or to facilitate the enhancement of communication and other transferable abilities that would increase the likelihood of integration in any socio-cultural environment.
} 